\title{
Formation of chlorinated breakdown products during degradation of sunscreen agent, 2-ethylhexyl-4-methoxycinnamate in the presence of sodium hypochlorite
}

\author{
Alicja Gackowska ${ }^{1}$ - Maciej Przybyłek ${ }^{2}$ • Waldemar Studziński ${ }^{1}$ • \\ Jerzy Gaca ${ }^{1}$
}

Received: 2 June 2015 / Accepted: 15 September 2015 / Published online: 26 September 2015

(C) The Author(s) 2015. This article is published with open access at Springerlink.com

\begin{abstract}
In this study, a new degradation path of sunscreen active ingredient, 2-ethylhexyl-4-methoxycinnamate (EHMC) and 4-methoxycinnamic acid (MCA) in the presence of sodium hypochlorite $(\mathrm{NaOCl})$, was discussed. The reaction products were detected using gas chromatography-mass spectrometry (GC-MS). Since HOCl treatment leads to more polar products than EHMC, application of polar extracting agents, dichloromethane and ethyl acetate/n-hexane mixture, gave better results in terms of chlorinated breakdown products identification than n-hexane. Reaction of EHMC with $\mathrm{HOCl}$ lead to the formation of $\mathrm{C}=\mathrm{C}$ bridge cleavage products such as 2-ethylhexyl chloroacetate, 1-chloro-4-methoxybenzene, 1,3-dichloro-2methoxybenzene, and 3-chloro-4-methoxybenzaldehyde. High reactivity of $\mathrm{C}=\mathrm{C}$ bond attached to benzene ring is also characteristic for MCA, since it can be converted in the presence of HOCl to 2,4-dichlorophenole, 2,6-dichloro-1,4-benzoquinone, 1,3-dichloro-2-methoxybenzene, 1,2,4-trichloro-3methoxybenzene, 2,4,6-trichlorophenole, and 3,5-dichloro-2hydroxyacetophenone. Surprisingly, in case of EHMC/HOCl/ $\mathrm{UV}$, much less breakdown products were formed compared to
\end{abstract}

Responsible editor: Santiago V. Luis

Electronic supplementary material The online version of this article (doi:10.1007/s11356-015-5444-0) contains supplementary material, which is available to authorized users.

Maciej Przybyłek

m.przybylek@cm.umk.pl

1 Faculty of Chemical Technology and Engineering, University of Technology and Life Science, Seminaryjna 3,

85-326 Bydgoszcz, Poland

2 Department of Physical Chemistry, Collegium Medicum, Nicolaus Copernicus University, Kurpińskiego 5, 85-950 Bydgoszcz, Poland
non-UV radiation treatment. In order to describe the nature of EHMC and MCA degradation, local reactivity analysis based on the density functional theory (DFT) was performed. Fukui function values showed that electrophilic attack of $\mathrm{HOCl}$ to the $\mathrm{C}=\mathrm{C}$ bridge in EHMC and MCA is highly favorable (even more preferable than phenyl ring chlorination). This suggests that $\mathrm{HOCl}$ electrophilic addition is probably the initial step of EHMC degradation.

Keywords 2-Ethylhexyl-4-methoxycinnamate $\cdot$ Emerging pollutants $\cdot$ Chlorination $\cdot$ Sunscreen $\cdot$ Halogenated disinfection byproducts $\cdot$ GC-MS $\cdot$ Local reactivity $\cdot$ Fukui function

\section{Introduction}

Sodium hypochlorite is one of the most commonly used disinfectants in water treatment. Under the aqueous conditions it can be hydrolyzed to hypochlorous acid ( $\mathrm{HOCl})$. Since $\mathrm{HOCl}$ reveal a high chlorinating and oxidizing activity, it is often classified both to the reactive oxygen and chlorine species. The pollutants which are formed via dissolved organic matter conversion in the presence of chlorine disinfectants are called halogenated disinfection by-products (HDBPs). Generally speaking, this class of pollutants comprises trihalomethanes (THMs), haloacetic acids, haloacetonitriles (HANs), and haloketones (HKs) (Boorman 1999). HDBPs can be formed through the transformation of naturally occurring compounds like humic and fulvic acids (Ristoiu et al. 2009). However, many studies have been also focused on purely anthropogenic HDBPs (Negreira et al. 2008; Nakajima et al. 2009; Santos et al. 2013; Solakyildirim et al. 2014; Bulloch et al. 2015) which can be formed through pharmaceuticals and personal 
care product (PPCP) reactions with disinfectants. The use of PPCPs has dramatically increased since the late 1990s. It is estimated that between 1999 and 2009, the annual PPCP consumption in the USA has grown from 2 billion to 3.9 billion (Tong et al. 2011). Since the influence of PPCPs on the ecosystems has not been fully studied, they are often classified as emerging pollutants (Gomez et al. 2012). In order to assess the levels of PPCPs in water bodies, several analytical methods, such as liquid chromatography-mass spectrometry positiveion electrospray (LC/MS-ESI(+)), high-performance liquid chromatography (HPLC), and gas chromatography-mass spectrometry (GC-MS), have been used (Kolpin et al. 2002).

Among many classes of PPCP pollutants, chemical ultraviolet filters (UV-F) deserve particular attention. These compounds are often used as cosmetics ingredients and polymeric material photostabilization agents. UV filters can be divided into two basic categories: organic and inorganic. The most common inorganic sunscreen agents are zinc oxide and titanium dioxide. On the other hand, organic UV filters comprise a wide group of compounds like cinnamates, benzophenones, salicylates, camphor derivatives, $p$-aminobenzoic acid, and benzimidazoles. It was estimated that the annual production of these compounds reached several thousand tons (Buser et al. 2006). The use of UV filters has grown recently as a result of increasing concern about sunlight exposure causing skin cancer (Gasparro 2000). Due to the popularity of sunscreen agents, numerous reports have appeared on their occurrence in the environment. Sunscreen agents are present in the surface waters (Straub 2002; Poiger et al. 2004; Tarazona et al. 2010), swimming pool waters (Cuderman and Heath 2007; Santos et al. 2012), drinking water (Loraine and Pettigrove 2006; Diaz-Cruz et al. 2012), wastewater (Damiani et al. 2006; Li et al. 2007; Rodil et al. 2012), and sewage sludge (De la Cruz et al. 2012; Zuloaga et al. 2012; Barón et al. 2013). The presence of UV filters in the environment poses a particular danger, since they are generally resistant to degradation during water treatment process (Oppenheimer and Stephenson 2006; Liu et al. 2012; Gao et al. 2013; Ramos et al. 2015).

Due to the low allergy risk (Kimura and Katoh 1995; Schauder and Ippen 1997) and good UV absorption properties (Santos et al. 2012), EHMC is one of the most popular sunscreen agent, which undoubtedly have an impact on the environment. Straub et al. (2002) found that the average concentration of EHMC in the River Rhine was $5.5 \mathrm{ng} / \mathrm{l}$. According to the same study, EHMC was found in the tissues of different fish species (Straub et al. 2002). Since most UV filters are lipophilic, they are able to bioaccumulate in the human body and aquatic organisms (Balmer et al. 2005; Fent et al. 2010). The negative effect of UV filter accumulation in living organisms was confirmed by many studies. Paredes et al. (2014) found that popular sunscreen agents, benzophenone-3 (BP-3), benzophenone-4 (BP-4), 2-ethylhexyl 4-methoxycinnamate (EHMC), and 4-methylbenzylidene-camphor (4-MBC), are significantly toxic for several different marine organisms. Furthermore, UV filters can cause endocrine disorders (Schlumpf et al. 2001; Heneweer et al. 2005; Kunz et al. 2006; Schlecht et al. 2006; Brausch et al. 2011). Sunscreens agent endocrine disrupting activity was described for human cells (Schlumpf et al. 2001; Heneweer et al. 2005), recombinant yeast with the human receptor of estrogen (Kunz et al. 2006), rodents (Schlumpf et al. 2001; Schlecht et al. 2006), and aquatic organisms (Brausch et al. 2011).

One of the routes by which UV filters and their chlorinated by-products may enter the environment is through disposal of the chlorinated water from swimming pools. According to the literature (Nakajima et al. 2009; Santos et al. 2013), the main by-products of EHMC transformations in the presence of $\mathrm{HOCl}$ are chlorosubstituted EHMC derivatives. These compounds are formed via electrophilic aromatic substitution reaction (Santos et al. 2013). Generally, there are two types of chlorination mechanisms occurring under water treatment conditions: electrophilic substitution and addition to unsaturated bond (Deborde et al. 2008). According to the Fukui function concept which is based on the frontier molecular orbital (FMO) theory and density functional theory (DFT), susceptibility of particular atoms to the nucleophilic, electrophilic, and radical attack can be directly evaluated from the atomic charge population analysis (Yang and Mortier 1986). Noteworthy, Fukui function has been applied in many important areas such as environmental fate assessment (zen et al. 2003; De Witte et al. 2009; Butler et al. 2010; Barr et al. 2012; Rokhina et al. 2012; Altarawneh et al. 2015), pollutant sorption and catalytic degradation (Chatterjee et al. 2000; Chatterjee et al. 2002; Chatterjee et al. 2003; Bekbolet et al. 2009; Musa et al. 2012; Pan et al. 2014; Palma-Goyes et al. 2015), and toxicity prediction of chlorinated benzenes (Padmanabhan et al. 2005, 2006), biphenyls (Parthasarathi et al. 2003; Parthasarathi et al. 2004; Padmanabhan et al. 2005), dibenzofuranes (Sarkar et al. 2006), and phenols (Padmanabhan et al. 2006).

Although it has been reported that EHMC undergoes degradation in the presence of UV light and different oxidizing and chlorinating agents (Nakajima et al. 2009; MacManusSpencer et al. 2011; Gackowska et al. 2014), there is no comprehensive report dealing with the formation of EHMC chlorinated breakdown products under the water chlorination conditions. However, this is a complex issue, since there are many factors which can affect degradation of UV filters such as sunlight radiation, $\mathrm{pH}$, and dissolved organic and inorganic compounds (Sakkas et al. 2003, Nakajima et al. 2009; Jammoul et al. 2009; Zhang et al. 2010; Zhou et al. 2013). The present first-principle study aims to determine what breakdown products are formed in case of the simple model containing EHMC and disinfecting agent. In order to gain better insight into this question, experimental results were supported with Fukui function value analysis. 


\section{Materials and methods}

\section{Materials}

All chemicals were used without further purification. 2Ethylhexyl 4-methoxycinnamate (EHMC) (98\%) and 4methoxycinnamic acid (MCA) $(99 \%)$ were obtained from ACROS Organics and were kept in lightproof container at $4{ }^{\circ} \mathrm{C}$. Other chemicals used in the study, sodium hypochlorite $(100 \mathrm{~g} / \mathrm{l}$ available $\mathrm{Cl})$ anhydrous $\mathrm{Na}_{2} \mathrm{SO}_{4}$, dichloromethane, methanol ( $96 \%$ ) were purchased from POCH S.A. (Poland). Ethyl acetate and n-hexane were obtained from SigmaAldrich.

\section{Reaction conditions and analytical procedures}

One thousand milliliters of $\mathrm{EHMC} / \mathrm{NaOCl}$ and $\mathrm{MCA} / \mathrm{NaOCl}$ reaction mixtures were prepared by dissolving EHMC and MCA in $1 \mathrm{ml}$ of methanol, diluting with distilled water and adding $\mathrm{NaOCl}$ water solution. This procedure was based on the approaches reported in previous works (Giokas et al. 2004; Nakajima et al. 2009; MacManus-Spencer et al. 2011) according to which small amounts of methanol are used in order to improve EHMC solubility. The concentration of EHMC and MCA in the mixture was $3.4 \cdot 10^{-4} \mathrm{M}$, while the concentration of sodium hypochlorite was $1.7 \cdot 10^{-5} \mathrm{M}$. Immediately after the mixtures were prepared, they were transferred to the reactor. The temperature in the reactor was ranged from 22 to $25{ }^{\circ} \mathrm{C}$. During the reaction, samples of $100 \mathrm{ml}$ were collected at different time intervals and subjected to the extraction using $20 \mathrm{ml}$ of extracting agent (n-hexane, ethyl acetate/n-hexane 1:1 mixture and dichloromethane). This procedure was carried out for $10 \mathrm{~min}$. Then, the extracts were allowed to stand for $30 \mathrm{~min}$ at room temperature and dried using anhydrous $\mathrm{Na}_{2} \mathrm{SO}_{4}$. So, prepared samples were analyzed by GC-MS method. The temperature and $\mathrm{pH}$ of reaction mixtures were measured at each sample collection using a $\mathrm{pH}$ meter equipped with a temperature probe (CX-501 Multifunction Meter Elmetron, Poland). All reactions (with and without UV radiation exposure) were carried out in a stirred (200 rpm) and water-cooled cylindrical glass photoreactor of 650-ml capacity (Heraeus, Germany) equipped with a medium pressure mercury lamp (Heraeus, TQ $150 \mathrm{~W}$ ), which can emit radiation in the 200-600-nm range (radiant flux $6.2 \mathrm{~W}$ for UV-C, 3.6 W for UV-B, and 4.5 W for UV-A). In case of photodegradation reactions, the samples were irradiated during all the experimental time (180 $\mathrm{min}$.).

A GC-MS 5890 HEWLETT PACKARD instrument equipped with column ZB-5MS $(0.25 \mathrm{~mm} \times 30 \mathrm{~m} \times 0.25 \mu \mathrm{m})$ was used for the identification of the transformation products applying the following chromatographic conditions: injector temperature $250^{\circ} \mathrm{C}$, oven temperature program from $80^{\circ} \mathrm{C}$ to $260^{\circ} \mathrm{C}$ at $10^{\circ} \mathrm{C} / \mathrm{min}$, from $260^{\circ} \mathrm{C}$ to $300^{\circ} \mathrm{C}$ (held for $2 \mathrm{~min}$ ) at a rate of $5{ }^{\circ} \mathrm{C}$ min. Helium was used as a carrier gas. The volume of the sample was $1 \mu \mathrm{l}$. Reaction products were identified by comparing recorded MS spectra with standard spectra from NIST/EPA/NIH Mass Spectral Library. This was done automatically using probability-based matching (PBM) mass spectrometry library search algorithm provided by HP ChemStation 3.0 software package.

\section{Fukui function calculations}

All geometry optimizations were performed using Becke three-parameter (B3) hybrid method (Becke 1988; Becke 1993) with the Lee-Yang-Parr (LYP) functional (Lee et al. 1988; Miehlich et al. 1989) and 6-31+G(d,p) basis set (Krishnan et al. 1980; McLean and Chandler 1980; Clark et al. 1983; Frisch et al. 1984). Since the molecular geometry of substrates depends on the interactions between the molecule and surrounding solvent, polarized continuum model (PCM) was used (Miertuš et al. 1981; Miertuš and Tomasi 1982). Frequency calculations were performed on the B3LYP/6-31+G(d,p) level and no-imaginary ones were found. All geometry optimizations and frequency calculations were conducted using Gaussian03 software (Frisch et al. 2003).

Nucleophilic, $f^{+}$, electrophilic $f^{-}$, and radical $f^{0}$ Fukui function values were calculated within $\mathrm{DMOL}^{3}$ (Delley 1990; Delley 1996; Delley 2000) module of Accelrys Material Studio 7.0 package (Accelrys Material Studio-Inc, 2014) using BLYP functional (Becke 1988; Lee et al. 1988; Miehlich et al. 1989) with DND basis set (version 3.5) (Delley 2006). Population analysis was performed using Hirshfeld method. The reliability of this procedure was confirmed by Thanikaivelan et al. (2002). Condensed nucleophilic, $f^{+}$, electrophilic $f^{-}$, and radical $f^{0}$ Fukui functions were calculated from Eq. (1-3) according to the method proposed by Yang and Mortier (Yang and Mortier 1986):

$f^{+}=q(N+1)-q(N)$

$f^{-}=q(N)-q(N-1)$

$f^{0}=\frac{q(N+1)-q(N-1)}{2}$

where $q$ is Hirshfeld charge population on atoms in the molecule and $N$ denotes number of electrons in optimized structure. Numbering of atoms is presented on Fig. 1.

\section{Results and discussion}

In order to evaluate the effect of $\mathrm{HOCl}$ on the stability and photostability of EHMC, GC-MS analyses of reaction mixtures were performed. Since MCA is known to be EHMC 
Fig. 1 Atom numbering in MCA $(\mathrm{R}=\mathrm{OH})$ and $\mathrm{EHMC}$ $\left(\mathrm{R}=\mathrm{OCH}_{2} \mathrm{CH}\left(\mathrm{C}_{2} \mathrm{H}_{5}\right) \mathrm{C}_{4} \mathrm{H}_{9}-\mathrm{n}\right)$

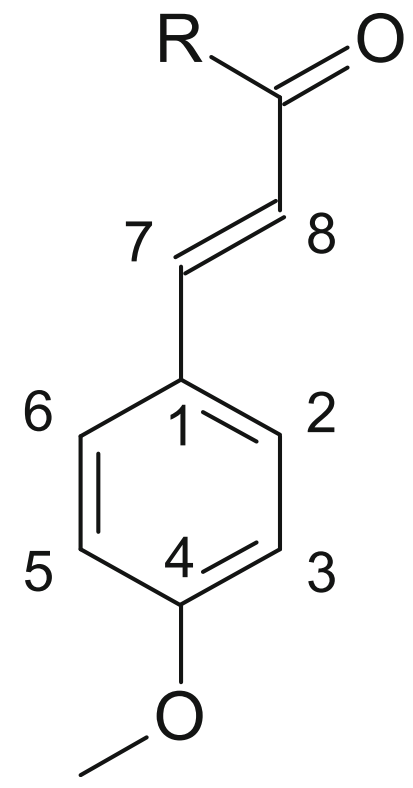

degradation product (MacManus-Spencer et al. 2011; Gackowska et al. 2014), reaction of MCA with $\mathrm{HOCl}$ was also examined. As it was mentioned, products were identified using PBM mass spectrometry library search method. For the analysis, only spectra with match probabilities above $95 \%$ were taken into account. Retention times and selected $\mathrm{m} / \mathrm{z}$ peaks are summarized in Table 1 . MS spectra of identified products are provided in the Online Resource.

Since the $\mathrm{pH}$ of obtained mixtures was ranged from 7.1 to 7.4 in case of $\mathrm{EHMC} / \mathrm{NaOCl}$ and from 6.9 to 7.2 in case of $\mathrm{MCA} / \mathrm{NaOCl}$, according to Henderson-Hasselbalch equation, $\mathrm{HOCl}$ is a dominating form $\left(\mathrm{p} K_{\mathrm{a}}=7.5\right)$. As it might be expected, under these conditions, EHMC undergoes chlorination which was also reported previously (Nakajima et al. 2009; Santos et al. 2013). GC-MS analysis showed that there are two compounds of molecular mass of $324 \mathrm{Da}$ (1EHMCCl and 2EHMCCl) (Table 1), which probably correspond to chlorinated EHMC derivatives. Noteworthy, $\mathrm{m} / \mathrm{z}$ signals of $1 \mathrm{EHMCCl}$ and 2EHMCCl (Fig. S4 and Fig. S5 in the Online Resource) are in accordance with monochlorinated EHMC fragmentation pattern reported in the literature (Nakajima et al. 2009; Santos et al. 2013). Low intense molecular peaks and the loss of $112 \mathrm{~m} / \mathrm{z}$ units on the mass spectra of EHMC and its monochlorinated derivatives (supplementary Fig. S1, Fig. S2, Fig. S4, Fig. S5) indicates fast fragmentation wherein the first step is the McLafferty rearrangement. As one might expect, MS spectra recorded for E-EHMC and ZEHMC are almost identical, and hence, they can be distinguished only by their retention times (Table 1). Z-EHMC, which is known to be more polar than $\mathrm{E}$ isomer (Pattanaargson et al., 2004), is represented on the GC chromatogram by small peak of a lower retention time that EEHMC (Fig. 2a). As in case of EHMC and Z-EHMC, $1 \mathrm{EHMCCl}$ and $2 \mathrm{EHMCCl}$ have very similar mass spectra but different retention times indicating they are also geometric isomers. According to Nakajima et al. 2009, peaks at $\mathrm{m} / \mathrm{z} 195$ and 212 in the monochlorinated EHMC MS spectra correspond to $\left[\mathrm{C}_{10} \mathrm{H}_{8} \mathrm{ClO}_{2}{ }^{+}\right]$and $\left[\mathrm{C}_{10} \mathrm{H}_{9} \mathrm{ClO}_{3}{ }^{+}\right]$fragments (Nakajima et al. 2009). Since there are two of the most abundant chlorine isotopes ${ }^{35} \mathrm{Cl}$ and ${ }^{37} \mathrm{Cl}, 195$ and $212 \mathrm{~m} / \mathrm{z}$ peaks on the $1 \mathrm{EHMCCl}$ and $2 \mathrm{EHMCCl}$ mass spectra are near to the less intense peaks having $\mathrm{m} / \mathrm{z}$ of 197 , and 214 respectively (supplementary Fig. S4 and Fig S5). This chlorine isotope signature is typical for monochlorinated compounds. Therefore, as one can see from Fig. S6 in the Online Resource, two molecular peaks at $m / z=142$ and 144 can be found on the 1-chloro-4-methoxybenzene MS spectra. On the other hand, in case of dichlorinated molecules due to the three combinations of chlorine isotopes $\left({ }^{35} \mathrm{Cl} /{ }^{35} \mathrm{Cl},{ }^{35} \mathrm{Cl} /{ }^{37} \mathrm{Cl}\right.$, and ${ }^{37} \mathrm{Cl} /{ }^{37} \mathrm{Cl}$ ), there are three MS signals comprising the chlorine isotope profile. This pattern can be observed for molecular peaks of 1,3-dichloro-2-methoxybenzene $(\mathrm{m} / \mathrm{z}=176,178$, and 180), 2,4-dichlorophenole $(m / z=162,164$, and 166), and 2,6-dichloro-1,4-benzoquinone $(\mathrm{m} / \mathrm{z}=176,178$, and 180) (supplemental Fig. S7, Fig. S9, and Fig. S10).

As it can be inferred from Table 1, the diversity of detected products is dependent on the solvent used in the extraction step. In order to examine this question, the extraction procedure was performed using non-polar solvent, $\mathrm{n}$-hexane, and polar solvents, dichloromethane and ethyl acetate/n-hexane (1:1) It is worth mentioning that acetate/n-hexane system was found to be a good extracting agent for mixtures containing polar and non-polar compounds (Strati and Oreopoulou 2011). Furthermore, binary solvents such as ethyl acetate/n-hexane and dichloromethane/ethyl acetate were applied in case of EHMC and octyl dimethyl-p-aminobenzoate (ODPABA) chlorinated products extraction (Sakkas et al. 2003; Nakajima et al. 2009). The choice of a suitable solvent is of course related to the polarity of analytes. According to our results, more compounds were detected when ethyl acetate/n-hexane and dichloromethane were used than when the samples were extracted with non-polar n-hexane (Table 1). Noteworthy, good extracting properties of dichloromethane were confirmed in case of both hydrophilic compounds like chlorophenols (Yasman et al. 2006) and hydrophobic compounds like fatty acids and sterols (Chen et al. 1981). On the basis of retention time analysis, MacManus-Spencer et al. (2011) found that most of degradation products formed via EHMC photolysis are generally more polar than EHMC. A similar observation can be made in case of $\mathrm{EHMC/HOCl}$ system, since GC-MS retention time values of chlorinated degradation products like 1-chloro-4-methoxybenzene, 1,3-dichloro-2methoxybenzene, 2-ethylhexyl chloroacetate, and 3-chloro-4methoxybenzaldehyde are lower than retention times of EEHMC and Z-EHMC (Table 1).

The effect of UV radiation on the stability of the EHMC has been described in many studies (Morlière et al. 1982; Pattanaargson and Limphong 2001; Pattanaargson et al., 
Table 1 GC retention times and selected mass spectra data of detected in the reaction mixtures by-products

\begin{tabular}{|c|c|c|c|c|}
\hline Compound & $\begin{array}{l}\text { Retention time } \\
{[\mathrm{min}]}\end{array}$ & Proposed formulae & $\begin{array}{l}\text { Calculated } \\
\log \mathrm{P}^{\mathrm{a}}\end{array}$ & Selected $m / z$ signals ( $\%$ of base peak) \\
\hline \multicolumn{5}{|l|}{ EHMC/NaOCl (n-hexane extract) } \\
\hline Z-EHMC & 18.32 & $\mathrm{C}_{18} \mathrm{H}_{26} \mathrm{O}_{3}$ & 5.38 & $290(6), 178(100), 161(62)$ \\
\hline E-EHMC & 19.59 & $\mathrm{C}_{18} \mathrm{H}_{26} \mathrm{O}_{3}$ & 5.38 & $290(6), 178(100), 161(60)$ \\
\hline \multicolumn{5}{|c|}{$\mathrm{EHMC} / \mathrm{NaOCl}$ (ethyl acetate/ $n$-hexsane extract) } \\
\hline 2-Ethylhexyl chloroacetate & 8.74 & $\mathrm{C}_{10} \mathrm{H}_{19} \mathrm{ClO}_{2}$ & 3.48 & 112 (15), 83 (29), 70 (84), 57 (100) \\
\hline Z-EHMC & 18.22 & $\mathrm{C}_{18} \mathrm{H}_{26} \mathrm{O}_{3}$ & 5.38 & $290(5), 178(100), 161(59)$ \\
\hline 1EHMCCl & 19.22 & $\mathrm{ClC}_{18} \mathrm{H}_{25} \mathrm{O}_{3}$ & 5.98 & 324 (17), $212(100), 176(63)$ \\
\hline E-EHMC & 19.89 & $\mathrm{C}_{18} \mathrm{H}_{26} \mathrm{O}_{3}$ & 5.38 & $290(6), 178(100), 161(61)$ \\
\hline 2EHMCCl & 21.31 & $\mathrm{ClC}_{18} \mathrm{H}_{25} \mathrm{O}_{3}$ & 5.98 & 324 (16), $212(100), 176(73)$ \\
\hline \multicolumn{5}{|c|}{$\mathrm{EHMC} / \mathrm{NaOCl}$ (dichloromethane extract) } \\
\hline 1-Chloro-4-methoxybenzene & 5.54 & $\mathrm{ClC}_{6} \mathrm{H}_{4} \mathrm{OCH}_{3}$ & 2.42 & 142 (100), 127 (71), 99 (98) \\
\hline 1,3-Dichloro-2-methoxybenzene & 8.14 & $\mathrm{Cl}_{2} \mathrm{C}_{6} \mathrm{H}_{3} \mathrm{OCH}_{3}$ & 3.02 & $176(95), 161(100), 133(98)$ \\
\hline 2-Ethylhexyl chloroacetate & 8.85 & $\mathrm{C}_{10} \mathrm{H}_{19} \mathrm{ClO}_{2}$ & 3.48 & $112(17), 83(31), 70$ (86), 57 (100) \\
\hline 3-Chloro-4-methoxybenzaldehyde & 10.70 & $\mathrm{ClC}_{6} \mathrm{H}_{3}(\mathrm{CHO}) \mathrm{OCH}_{3}$ & 2.13 & 169 (100), $141(13), 126(21)$ \\
\hline Z-EHMC & 18.34 & $\mathrm{C}_{18} \mathrm{H}_{26} \mathrm{O}_{3}$ & 5.38 & 290 (6), 178 (100), $161(60)$ \\
\hline 1EHMCCl & 19.36 & $\mathrm{ClC}_{18} \mathrm{H}_{25} \mathrm{O}_{3}$ & 5.98 & $324(17), 212(100), 176(61)$ \\
\hline E-EHMC & 20.0 .3 & $\mathrm{C}_{18} \mathrm{H}_{26} \mathrm{O}_{3}$ & 5.38 & 290 (6), 178 (100), $161(61)$ \\
\hline 2EHMCCl & 21.45 & $\mathrm{ClC}_{18} \mathrm{H}_{25} \mathrm{O}_{3}$ & 5.98 & $324(11), 212(100), 176(74)$ \\
\hline \multicolumn{5}{|c|}{$\mathrm{MCA} / \mathrm{NaOCl}$ (ethyl acetate/n-heksane extract) } \\
\hline 2,4-Dichlorophenole & 6.32 & $\mathrm{Cl}_{2} \mathrm{C}_{6} \mathrm{H}_{3} \mathrm{OH}$ & 2.88 & $162(100), 126(18), 98(50)$ \\
\hline 2,6-Dichloro-1,4-benzoquinone & 7.12 & $\mathrm{Cl}_{2} \mathrm{C}_{6} \mathrm{H}_{2} \mathrm{O}_{2}$ & 1.80 & 176 (77), $148(18), 120(52), 88$ (86), 60 (100), 53 (90) \\
\hline 1,3-Dichloro-2-methoxybenzene & 7.88 & $\mathrm{Cl}_{2} \mathrm{C}_{6} \mathrm{H}_{3} \mathrm{OCH}_{3}$ & 3.02 & $176(98), 161(100) 133(97)$ \\
\hline 1,2,4-Trichloro-3-methoxybenzene & 8.46 & $\mathrm{Cl}_{3} \mathrm{C}_{6} \mathrm{H}_{2} \mathrm{OCH}_{3}$ & 3.63 & $210(62), 195$ (100), 167 (70) \\
\hline 2,4,6-Trichlorophenole & 8.89 & $\mathrm{Cl}_{3} \mathrm{C}_{6} \mathrm{H}_{2} \mathrm{OH}$ & 3.48 & $196(100), 160(18) 132(59)$ \\
\hline 3,5-Dichloro-2-hydroxyacetophenone & 15.21 & $\mathrm{Cl}_{2} \mathrm{C}_{6} \mathrm{H}_{2}(\mathrm{OH}) \mathrm{COCH}_{3}$ & 3.09 & 189 (100), $123(41), 75(46)$ \\
\hline \multicolumn{5}{|c|}{ EHMC/UV (ethyl acetate/n-heksane extract) } \\
\hline 2-Ethylhexyl alcohol & 4.28 & $\mathrm{C}_{8} \mathrm{H}_{18} \mathrm{O}$ & 2.50 & $112(5), 98(7), 83$ (17), 70 (22), 57 (100) \\
\hline Z-EHMC & 18.29 & $\mathrm{C}_{18} \mathrm{H}_{26} \mathrm{O}_{3}$ & 5.38 & $290(6), 178(100), 161(63)$ \\
\hline E-EHMC & 19.88 & $\mathrm{C}_{18} \mathrm{H}_{26} \mathrm{O}_{3}$ & 5.38 & 290 (7), $178(100), 161(60)$ \\
\hline \multicolumn{5}{|c|}{$\mathrm{EHMC} / \mathrm{NaOCl} / \mathrm{UV}$ (ethyl acetate/n-heksane extract) } \\
\hline 2-Ethylhexyl alcohol & 4.22 & $\mathrm{C}_{8} \mathrm{H}_{18} \mathrm{O}$ & 2.50 & $112(6), 98(7), 83(18), 70(25), 57$ (100) \\
\hline Z-EHMC & 18.20 & $\mathrm{C}_{18} \mathrm{H}_{26} \mathrm{O}_{3}$ & 5.38 & 290 (7), 178 (100), $161(61)$ \\
\hline 1EHMCCl & 19.11 & $\mathrm{ClC}_{18} \mathrm{H}_{25} \mathrm{O}_{3}$ & 5.98 & $324(18), 212(100), 176(63)$ \\
\hline E-EHMC & 19.73 & $\mathrm{C}_{18} \mathrm{H}_{26} \mathrm{O}_{3}$ & 5.38 & 290 (6), 178 (100), $161(62)$ \\
\hline 2EHMCCl & 21.15 & $\mathrm{ClC}_{18} \mathrm{H}_{25} \mathrm{O}_{3}$ & 5.98 & $324(10), 212(100), 176(76)$ \\
\hline
\end{tabular}

${ }^{\mathrm{a}} \log \mathrm{P}$ values were calculated using Marvin Sketch (https://www.chemaxon.com/)

2004; Rodil et al. 2009; Mac-Manus-Spencer et al. 2011; Miranda et al. 2014). According to our results, it takes ca. 60 min until the E-Z equilibrium is reached (Fig. 3a) under chlorine-free UV treatment conditions. In case of, $\mathrm{EHMC} / \mathrm{HOCl} / \mathrm{UV}$ (Fig. 3b) at the beginning of the process, $\mathrm{E}-\mathrm{Z}$ isomerisation is the main reaction and after the $\mathrm{E}-\mathrm{Z}$ equilibrium is reached, Z-EHMC undergoes transformations leading to the monochlorosubstituted derivatives and photodegradation products (Table 1). Surprisingly, much less breakdown products are formed when the $\mathrm{EHMC} / \mathrm{HOCl}$ mixture was subjected to the UV light then when the reaction was carried out in the dark (Fig. 2). As one can see, the intensities of GC peaks of $\mathrm{EHMC} / \mathrm{HOCl}$ are generally higher than appropriate signals recorded for $\mathrm{EHMC} / \mathrm{HOCl} / \mathrm{UV}$. This shows that EHMC degradation is more effective when UV irradiation is applied. According to many studies, exposure to the UV light combined with $\mathrm{Cl}_{2}, \mathrm{O}_{3}$, and $\mathrm{H}_{2} \mathrm{O}_{2}$ addition generally gives better results in terms of the removal of pollutants than in cases when UV irradiation was not used (Wols et al. 2013; Gong et al. 2015; Nam et al. 2015). 
Fig. 2 Exemplary gas chromatograms of EHMC/HOCl (a) and $\mathrm{EHMC} / \mathrm{HOCl} / \mathrm{UV}$ (b)

\section{a}

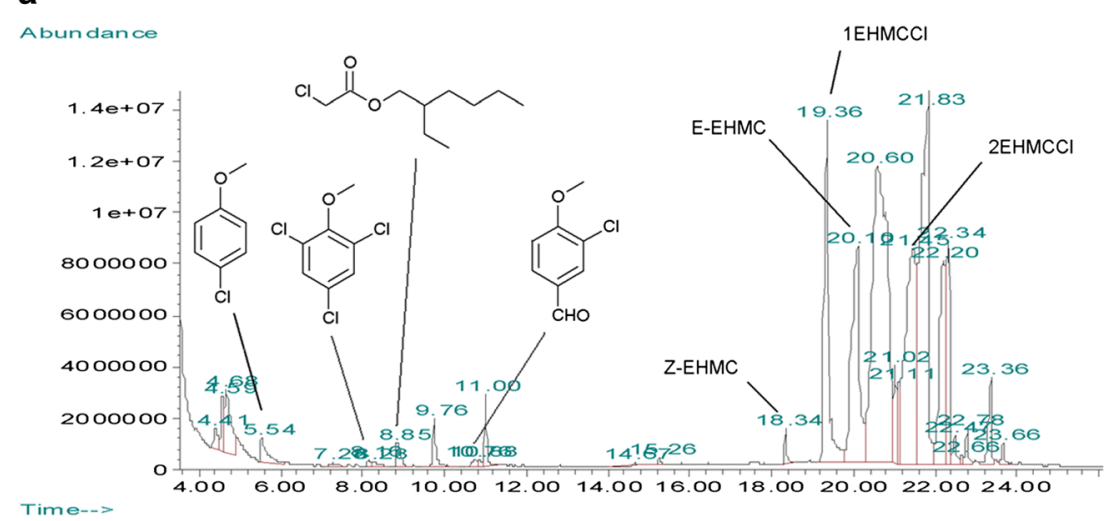

b

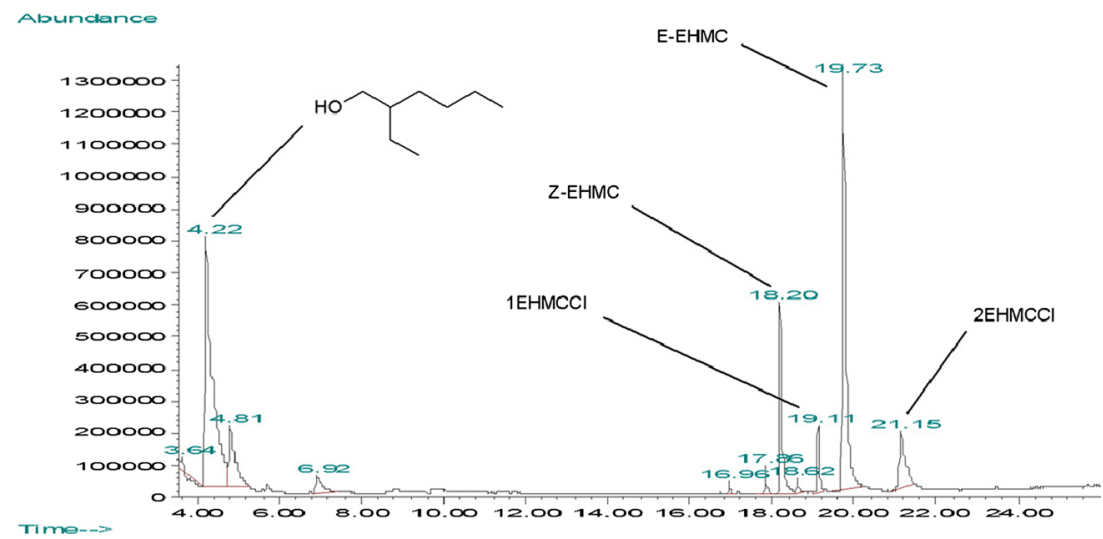

According to prior studies, EHMC can undergo photolysis leading to MCA and 2-ethylhexyl alcohol (Nakajima et al. 2009; Manus-Spencer et al. 2011; Gackowska et al., 2014). Obviously, MCA and 2-ethylhexyl alcohol can be formed also through the hydrolysis when the reaction mixture is not exposed to the UV radiation. Interestingly, reaction of MCA with $\mathrm{HOCl}$ results in the formation of acetophenone derivative, 3, 5-dichloro-2-hydroxyacetophenone. According to Hilton et al. (1990), acetophenone can be formed via cinnamic acid degradation according to the mechanism which proceeds in several steps, including water addition to $\mathrm{C}=\mathrm{C}$ bridge, dehydrogenating oxidation, tautomerization, and decarboxylation. The high reactivity of $\mathrm{C}=\mathrm{C}$ bond in cinnamic acid derivatives can be observed also in case of EHMC. As it can be seen from Fig. 4, although in case of EHMC, a large $\mathrm{COOCH} 2 \mathrm{CH}(\mathrm{C} 2 \mathrm{H} 5) \mathrm{C} 4 \mathrm{H} 9-\mathrm{n}$ group is attached to $\mathrm{C}=\mathrm{C}$ bond, there is no steric effect that would hinder electrophilic attack to $\mathrm{C}=\mathrm{C}$ bridge. Besides, negligible steric effect can be also confirmed by the fact that EHMC undergoes [2+2] cycloaddition reaction and radical attack of ${ }^{1} \mathrm{O}_{2}$ resulting in the formation of 4-methoxybenzaldehyde and 2-ethylhexyl acetate (MacManus-Spencer et al. 2011).

The abovementioned examples suggest that $\mathrm{C}=\mathrm{C}$ bridge is highly susceptible for electrophilic and radical attack. This can be explained using Fukui function analysis (Table 2) performed for optimized E-EHMC, Z-EHMC, E-MCA, and Z-MCA structures (Fig. 4). The greater the Fukui function value of a given atom is, the higher its local reactivity. In case of EHMC and MCA molecules, electron donating (OMe) group is conjugated with electron withdrawing carboxylic and ester group promoting electrophilic attack to C-3 and C5 carbon atoms (atoms numbering according to Fig. 1). As one can see (Table 2), electrophilic Fukui function $f$ values calculated for C-3 and C-5 atoms are higher than those calculated for C-2 and C-6 atoms which is in accordance with electron donating/withdrawing nature of attached substituents. Fukui function analysis showed that C-8 atom is even more susceptible for electrophilic attack than C-3 and C-5 carbon atoms. Interestingly, C-8 atom is also the most reactive in terms of radical attack. Although $\mathrm{HOCl}$ exhibits mainly electrophilic properties (Deborde et al. 2008), $\mathrm{OH}^{\bullet}$ and $\mathrm{Cl}^{\bullet}$ can be formed during $\mathrm{HOCl}$ photolysis (Feng et al. 2007). Nevertheless, we did not detect $\mathrm{C} 7-\mathrm{C} 8$ bond cleavage products in case of $\mathrm{EHMC} / \mathrm{HOCl} / \mathrm{UV}$ system.

The accumulation of negative charge on the C-8 atom as compared to phenyl ring can be explained using resonance theory. According to one of the "resonance theory rules," the larger the distance between separated formal charges, the more energetically preferable structure and in turns its contribution to the resonance hybrid is higher. As it can be seen 
a

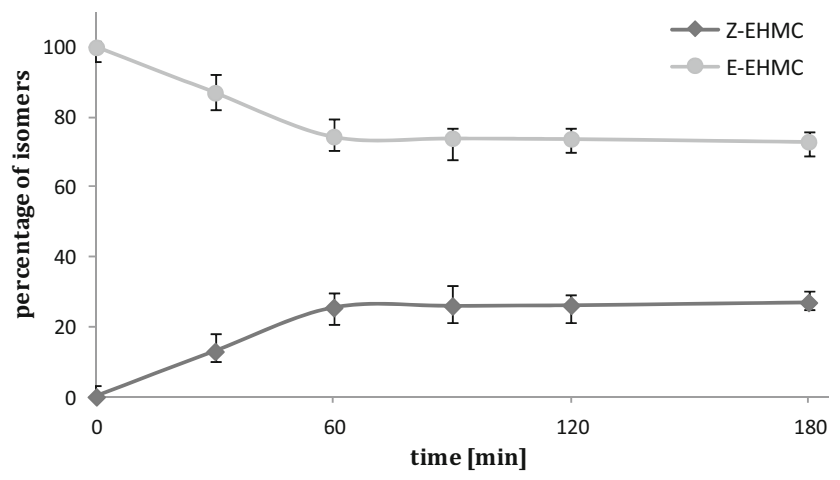

b

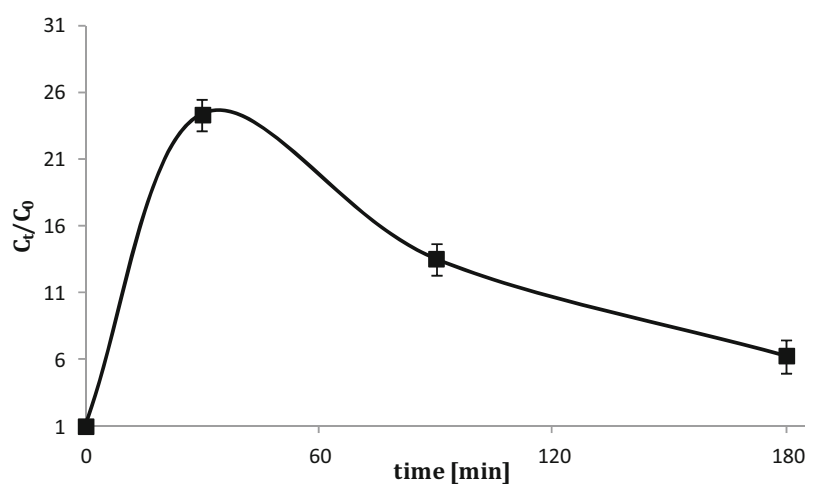

Fig. 3 Photoisomerisation of EHMC (a) and degradation of Z-EHMC in the presence $\mathrm{HOCl}$ and $\mathrm{UV}$ irradiation (b)

from Fig. 5, there is better charge separation in case of structure 3 than in case of structure 2 .

The products detected in the $\mathrm{EHMC} / \mathrm{HOCl}$ reaction mixtures suggest that EHMC degradation probably proceeds in many steps including chlorination, oxidation, and decarboxylation (Fig. 6). Although 3,5-dichloro-4-methoxybenzaldehyde and 3,5-dichloro-4-methoxybenzoic acid were not detected in the reaction mixture, formation of 1,3-dichloro-2methoxybenzene can be explained by the mechanism in which formyl group oxidation is followed by the decarboxylation. Noteworthy, the loss of carboxylic group attached to benzene ring can occur during water chlorination, since it was observed in case of 4-hydroxybenzoic acid (Larson and Rockwell 1979). It seems to be probable that some compounds which were formed in case of $\mathrm{MCA} / \mathrm{HOCl}$ can be also formed in case of EHMC/HOCl. The products identified during MCA degradation suggest that 1,3-dichloro-2-methoxybenzene (which was also detected in $\mathrm{EHMC} / \mathrm{HOCl}$ reaction mixture) can be further chlorinated to 1,2,4-trichloro-3-methoxybenzene (Table 1). The presence of chlorophenols and 2,6-dichloro-1,4-benzoquinone in the $\mathrm{MCA} / \mathrm{HOCl}$ reaction mixture can be explained by the fact that anisole derivatives, formed during EHMC and MCA degradation, can be demethylated under the water chlorination conditions (Lebedev et al. 2004) and then oxidized to quinones (Pi and Wang 2007).

\section{Conclusions}

In this study, new insight into the formation of EHMC disinfection by-products was presented. Reaction of EHMC with $\mathrm{HOCl}$ results in the formation of $\mathrm{C}=\mathrm{C}$ bridge cleavage products, 2-ethylhexyl chloroacetate, 1-chloro-4-methoxybenzene, 1,3-dichloro-2-methoxybenzene, and 3-chloro-4methoxybenzaldehyde. Interestingly, 2-ethylhexyl
Fig. 4 Visual representation of optimized E-MCA (a), Z-MCA (b), E-EHMC (c), and Z-EHMC (d) molecular structures a

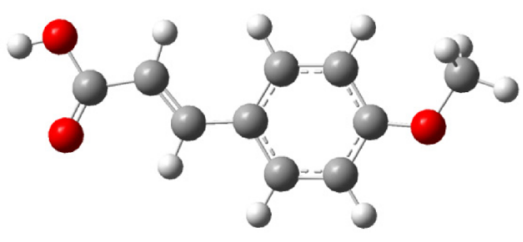

C

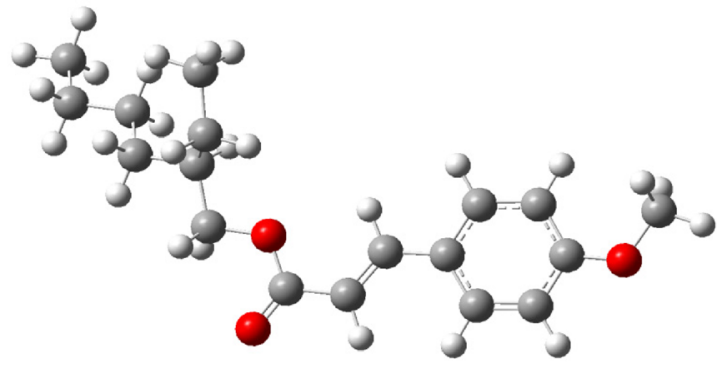

b

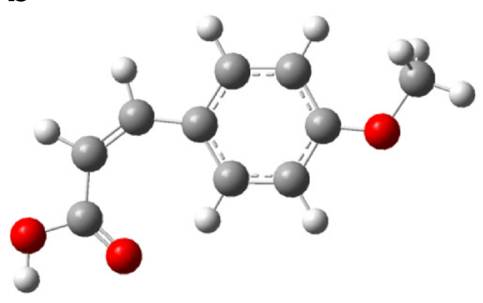

d

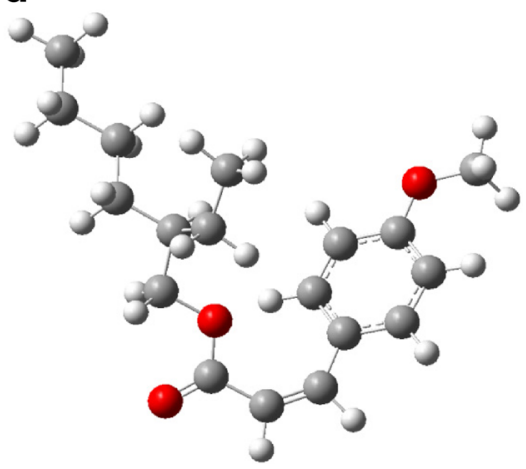


Table 2 Nucleophilic, $f^{+}$, electrophilic $f^{-}$, and radical $f^{0}$ Fukui function values calculated for E-MCA, Z-MCA, E-EHMC, and Z-EHMC

\begin{tabular}{|c|c|c|c|c|}
\hline \multirow[t]{2}{*}{ Compound } & \multirow[t]{2}{*}{ Atom } & \multicolumn{3}{|c|}{ Fukui function } \\
\hline & & $f^{+}$ & $f^{-}$ & $f^{0}$ \\
\hline \multirow[t]{8}{*}{ E-MCA } & $\mathrm{C}-1$ & 0.054 & 0.047 & 0.050 \\
\hline & $\mathrm{C}-2$ & 0.024 & 0.043 & 0.047 \\
\hline & $\mathrm{C}-3$ & 0.041 & 0.069 & 0.042 \\
\hline & $\mathrm{C}-4$ & 0.041 & 0.062 & 0.052 \\
\hline & C-5 & 0.062 & 0.062 & 0.062 \\
\hline & C-6 & 0.037 & 0.051 & 0.044 \\
\hline & $\mathrm{C}-7$ & 0.105 & 0.037 & 0.071 \\
\hline & C-8 & 0.084 & 0.102 & 0.093 \\
\hline \multirow[t]{8}{*}{ Z-MCA } & $\mathrm{C}-1$ & 0.020 & 0.071 & 0.045 \\
\hline & $\mathrm{C}-2$ & 0.039 & 0.037 & 0.038 \\
\hline & $\mathrm{C}-3$ & 0.037 & 0.059 & 0.048 \\
\hline & $\mathrm{C}-4$ & 0.061 & 0.061 & 0.061 \\
\hline & $C-5$ & 0.038 & 0.057 & 0.047 \\
\hline & C-6 & 0.051 & 0.051 & 0.051 \\
\hline & $\mathrm{C}-7$ & 0.109 & 0.036 & 0.072 \\
\hline & C-8 & 0.083 & 0.105 & 0.094 \\
\hline \multirow[t]{8}{*}{ E-EHMC } & $\mathrm{C}-1$ & 0.025 & 0.067 & 0.046 \\
\hline & $\mathrm{C}-2$ & 0.044 & 0.038 & 0.041 \\
\hline & $\mathrm{C}-3$ & 0.037 & 0.053 & 0.045 \\
\hline & $\mathrm{C}-4$ & 0.061 & 0.061 & 0.061 \\
\hline & C-5 & 0.037 & 0.055 & 0.046 \\
\hline & C-6 & 0.048 & 0.050 & 0.049 \\
\hline & $\mathrm{C}-7$ & 0.101 & 0.039 & 0.070 \\
\hline & C-8 & 0.086 & 0.104 & 0.095 \\
\hline \multirow[t]{8}{*}{ Z-EHMC } & $\mathrm{C}-1$ & 0.019 & 0.072 & 0.046 \\
\hline & $\mathrm{C}-2$ & 0.035 & 0.039 & 0.037 \\
\hline & $\mathrm{C}-3$ & 0.034 & 0.056 & 0.045 \\
\hline & C-4 & 0.056 & 0.062 & 0.059 \\
\hline & C-5 & 0.035 & 0.056 & 0.045 \\
\hline & C-6 & 0.045 & 0.051 & 0.048 \\
\hline & C-7 & 0.109 & 0.035 & 0.072 \\
\hline & C-8 & 0.088 & 0.096 & 0.092 \\
\hline
\end{tabular}

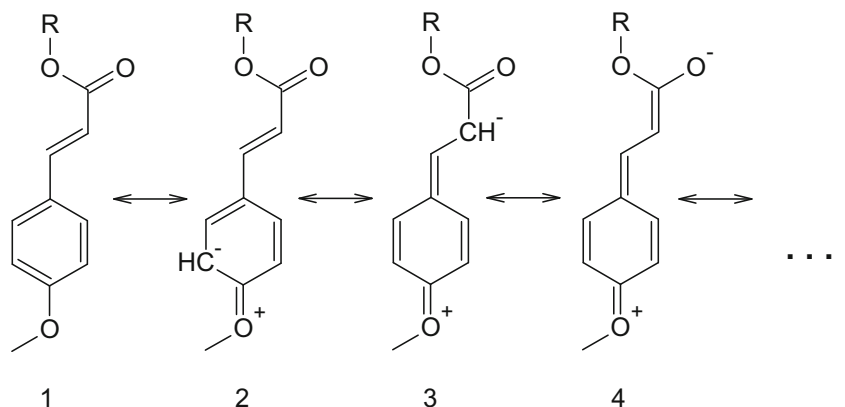

Fig. 5 Selected resonance structures of MCA $(\mathrm{R}=\mathrm{H})$ and EHMC $\left(\mathrm{R}=\mathrm{CH}_{2} \mathrm{CH}\left(\mathrm{C}_{2} \mathrm{H}_{5}\right) \mathrm{C}_{4} \mathrm{H}_{9}\right.$-n)

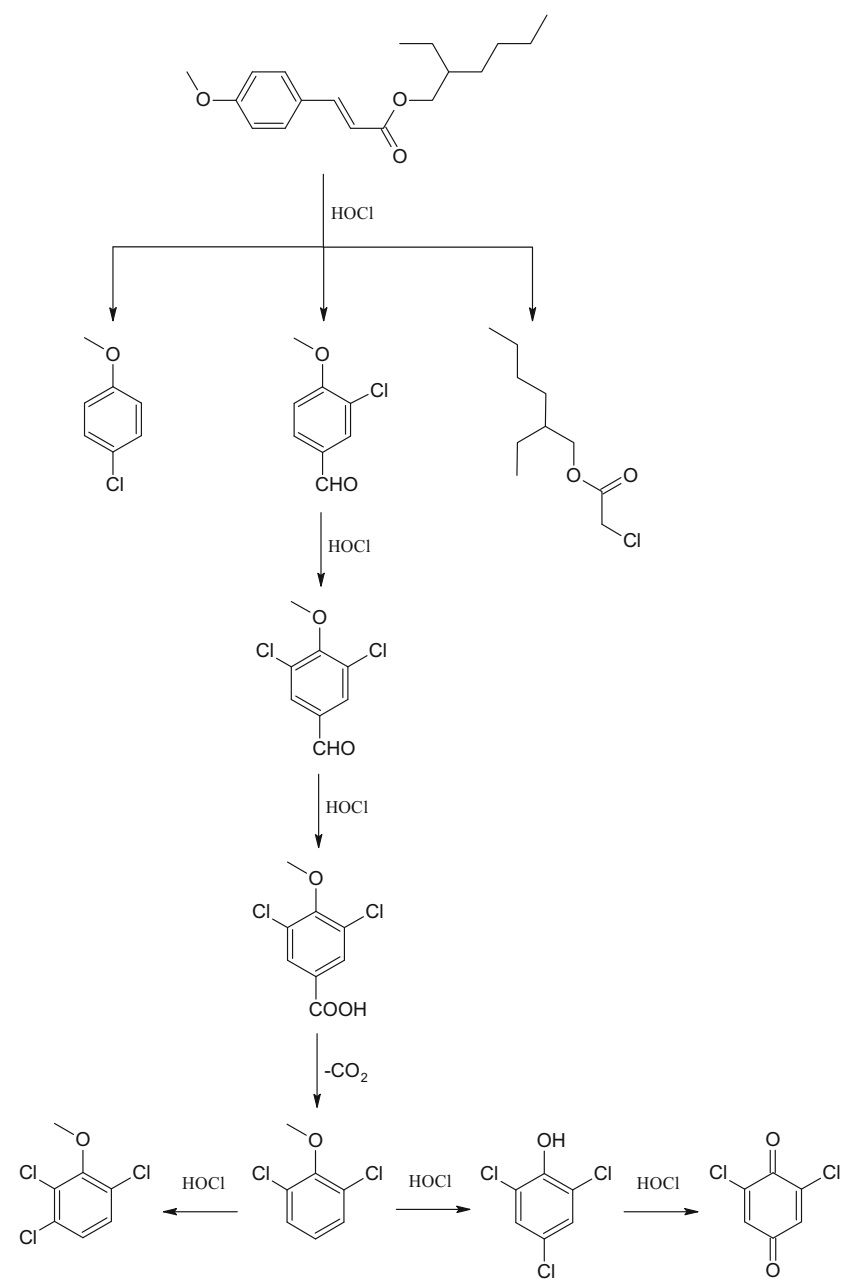

Fig. 6 Proposed pathways of EHMC chlorinated breakdown products formation based on products detected in $\mathrm{EHMC} / \mathrm{HOCl}$ and $\mathrm{MCA} / \mathrm{HOCl}$ reaction mixtures

chloroacetate was not detected in the EHMC/HOCl/UV mixture. In order to give a complete view of EHMC transformation under the influence of $\mathrm{HOCl}$ the reaction of EHMC hydrolysis and photolysis product, MCA (MacManus-Spencer et al. 2011; Gackowska et al. 2014) with $\mathrm{HOCl}$ was examined.

According to local reactivity analysis based on the Fukui function calculations, $\mathrm{C}=\mathrm{C}$ bond attached to the benzene ring in EHMC and MCA molecules is highly susceptible for electrophilic and radical attack. As it was reported previously, specific reactivity of $\mathrm{C}=\mathrm{C}$ bridge in case of cinnamic acid and its derivatives is manifested by [2+2] cycloaddition and photodegradation reactions (Egerton et al. 1981; Lewis et al. 1988; Robinet et al. 1987; Schrader et al. 1994; Broadbent et al. 1996; Hauri et al. 2004; MacManus-Spencer et al. 2011) and water addition (Hilton et al. 1990). Although it cannot be excluded that in case of $\mathrm{EHMC} / \mathrm{HOCl}$ system, formation of $\mathrm{C}=\mathrm{C}$ bond cleavage products is radical in nature, electrophilic attack of $\mathrm{HOCl}$ seems to be the initial step of degradation mechanism. 
GC/MS measurements showed that EHMC disinfection by-products are more polar than EHMC. For these reason, much more products were detected when dichloromethane and ethyl acetate/n-hexane 1:1 mixture was used as extracting solvent than $\mathrm{n}$-hexane. The polarity of compounds is a relevant parameter for both analytical procedure optimization and environmental risk assessment. Although hydrophilic chlorinated compounds not easily diffuse through cell membranes as hydrophobic compounds, they are also dangerous for water ecosystems. Chlorophenols and 2,6-dichloro-1,4-benzoquinone found in the $\mathrm{MCA} / \mathrm{HOCl}$ reaction mixture are wellknown toxic disinfection by-products which were identified in drinking water (Turnes et al. 1996; Michałowicz 2005; Simões et al. 2007; Qin et al. 2010). On the other hand, according to our best knowledge, there are no environmental monitoring reports on the 2-ethylhexyl chloroacetate occurrence in water bodies. This chlorinated EHMC breakdown product can be hydrolysed to chloroactetic acid which is known to be fitotoxic and cause serious environmental problems (Laturnus et al. 2005; Frank et al. 1994). Generally speaking, studies on the degradation of organic compounds in the presence of $\mathrm{HOCl}$ are useful for assessment of potential chloroorganic pollutant sources. Presented in this paper, results provide a good starting point for further studies on the UV filters chlorinated breakdown products formation.

Acknowledgments The authors gratefully acknowledge the help of Academic Computer Centre in Gdańsk in providing its facility to perform calculations presented in this study.

Open Access This article is distributed under the terms of the Creative Commons Attribution 4.0 International License (http:// creativecommons.org/licenses/by/4.0/), which permits unrestricted use, distribution, and reproduction in any medium, provided you give appropriate credit to the original author(s) and the source, provide a link to the Creative Commons license, and indicate if changes were made.

\section{References}

Accelrys Materials Studio 7-Inc., San Diego: Accelrys Software Inc. (2014)

Altarawneh M, Dlugogorski BZ (2015) Formation and chlorination of carbazole, phenoxazine, and phenazine. Environ Sci Technol 49: 2215-2221

Balmer ME, Buser HR, Muller MD, Poiger T (2005) Occurrence of some organic UV filters in wastewater, in surface waters, and in fish from Swiss lakes. Environ Sci Technol 39:953-962

Barón E, Gago-Ferrero P, Gorga M, Rudolph I, Mendoza G, Zapate AM, Díaz-Cruz S, Barra R, Ocampo-Duque W, Páez M, Dabra RM, Eljarrat E, Barceló D (2013) Occurrence of hydrophobic organic pollutants (BFRs and UV-filters) in sediments from South America. Chemosphere 92:309-316
Barr WJ, Yi T, Aga D, Acevedo O, Harper WF Jr (2012) Using electronic theory to identify metabolites present in $17 \alpha$-ethinylestradiol biotransformation pathways. Environ Sci Technol 46:760-768

Becke AD (1988) Density-functional exchange-energy approximation with correct asymptotic behavior. Phys Rev A 38:3098-3100

Becke AD (1993) Density-functional thermochemistry III. The role of exact exchange. J Chem Phys 98:5648-5652

Bekbolet M, Çınar Z, Kılıç M, Uyguner CS, Minero C, Pelizzetti E (2009) Photocatalytic oxidation of dinitronaphthalenes: theory and experiment. Chemosphere 75:1008-1014

Boorman GA (1999) Drinking water disinfection byproducts: review and approach to toxicity evaluation. Environ Health Perspect 107(Suppl 1):207-217

Brausch JM, Rand GM (2011) A review of personal care products in the aquatic environment: environmental concentrations and toxicity. Chemosphere 82:1518-1532

Broadbent JK, Martincigh BS, Raynor MW, Salter LF, Moulder R, Sjoberg P, Markides KE (1996) Capillary supercritical fluid chromatography combined with atmospheric pressure chemical ionization mass spectrometry for the investigation of photoproduct formation in the sunscreen absorber 2-ethylhexyl-p-methoxycinnamate. J Chromatogr A 732:101-110

Bulloch DN, Nelson ED, Carr SA, Wissman CR, Armstrong JL, Schlenk D, Larive CK (2015) Occurrence of halogenated transformation products of selected pharmaceuticals and personal care products in secondary and tertiary treated wastewaters from Southern California. Environ Sci Technol 49:2044-2051

Buser HR, Balmer ME, Schmid P, Kohler M (2006) Occurrence of UV filters 4-methylbenzylidene camphor and octocrylene in fish from various Swiss rivers with inputs from wastewater treatment plants. Environ Sci Technol 40:1427-1431

Butler M, Mañez PA, Cabrera GM (2010) An experimental and computational study on the dissociation behavior of hydroxypyridine $\mathrm{N}$ oxides in atmospheric pressure ionization mass spectrometry. J Mass Spectrom 45:536-544

Chatterjee A, Iwasaki T, Ebina T (2000) A novel way to design suitable inorganic material from the smectite family for sorption of 2,3,7,8tetrachlorinated dibenzo- $p$-dioxin. J Phys Chem A 104:2098-2104

Chatterjee A, Iwasaki T, Ebina T (2002) 2:1 Dioctahedral smectites as a selective sorbent for dioxins and furans: reactivity index study. J Phys Chem A 106:641-648

Chatterjee A, Ebina T, Onodera Y, Mizukami F (2003) 2,3,7,8Tetrachloro dibenzo- $p$-dioxin can be successfully decomposed over 2:1 dioctahedral smectite-a reactivity index study. J Mol Graph Model 22:93-104

Chen S, Shen CSJ, Sheppard AJ (1981) Comparison of methylene chloride and chloroform for the extraction of fats from food products. J Am Oil Chem Soc 58(5):599-601

Clark T, Chandrasekhar J, Spitznagel GW, von Rague Schleyer P (1983) Efficient diffuse function-augmented basis sets for anion calculations. III. The $3-21+\mathrm{G}$ basis set for first-row elements, Li-F. J Comput Chem 4:294-301

Cuderman P, Heath E (2007) Determination of UV filters and antimicrobial agents in environmental water samples. Anal Bioanal Chem 387(40):1343-1350

Damiani E, Rosati L, Castagna R, Carloni P, Greci L (2006) Changes in ultraviolet absorbance and hence in protective efficacy against lipid peroxidation of organic sunscreens after UVA irradiation. J Photochem Photobiol B 82:204-213

De la Cruz N, Giménez J, Esplugas S, Grandjean D, de Alencastro LF (2012) Degradation of 32 emergent contaminants by UV and neutral photo-Fenton in domestic wastewater effluent previously treated by activated sludge. Water Res 46:1947-1957

De Witte B, Van Langenhove H, Hemelsoet K, Demeestere K, De Wispelaere P, Van Speybroeck V, Dewulf J (2009) Levofloxacin 
ozonation in water: rate determining process parameters and reaction pathway elucidation. Chemosphere 76:683-689

Deborde M, von Gunten U (2008) Reactions of chlorine with inorganic and organic compounds during water treatment-kinetics and mechanisms: a critical review. Water Res 42:13-51

Delley B (1990) An all-electron numerical method for solving the local density functional for polyatomic molecules. J Chem Phys 92:508517

Delley B (1996) Fast calculation of electrostatics in crystals and large molecules. J Phys Chem 100:6107-6110

Delley B (2000) From molecules to solids with the DMol3 approach. J Chem Phys 113:7756-7764

Delley B (2006) Ground-state enthalpies: evaluation of electronic structure approaches with emphasis on the density functional method. J Phys Chem A 110:13632-13639

Diaz-Cruz MS, Gago-Ferrero P, Liorca M, Barcelo D (2012) Analysis of UV filters in tap water and other clean waters in Spain. Anal Bioanal Chem 402(7):2325-2333

Egerton PL, Hyde EM, Trigg J, Payne A, Beynon P, Mijovic MV, Reiser A (1981) Photocycloaddition in liquid ethyl cinnamate and in ethyl cinnamate glasses. The photoreaction as a probe into the micromorphology of the solid. J Am Chem Soc 103:3859-3863

Feng Y, Smith DW, Bolton JR (2007) Photolysis of aqueous free chlorine species ( $\mathrm{HOCl}$ and $\mathrm{OCl}-$ ) with $254 \mathrm{~nm}$ ultraviolet light. J Environ Eng Sci 6:277-284

Fent K, Zenker A, Rapp M (2010) Widespread occurrence of estrogenic UV-filters in aquatic ecosystems in Switzerland. Environ Pollut 158: $1817-1824$

Frank H, Scholl H, Renschen D, Rether B, Laouedj A, Norokorpi Y (1994) Haloacetic acids, phytotoxic secondary air pollutants. Environ Sci Pollut Res 1(1):4-14

Frisch MJ, Pople JA, Binkley JS (1984) Selfconsistent molecular orbital methods 25. Supplementary functions for Gaussian basis sets. J Chem Phys 80:3265-3269

Frisch MJ, Trucks GW, Schlegel HB, Scuseria GE, Robb MA, Cheeseman JR, Montgomery JA Jr, Vreven T, Kudin KN, Burant JC, Millam JM, Iyengar SS, Tomasi J, Barone V, Mennucci B, Cossi M, Scalmani G, Rega N, Petersson GA, Nakatsuji H, Hada M, Ehara M, Toyota K, Fukuda R, Hasegawa J, Ishida M, Nakajima T, Honda Y, Kitao O, Nakai H, Klene M, Li X, Knox JE, Hratchian HP, Cross JB, Adamo C, Jaramillo J, Gomperts R, Stratmann RE, Yazyev O, Austin AJ, Cammi R, Pomelli C, Ochterski JW, Ayala PY, Morokuma K, Voth GA, Salvador P, Dannenberg JJ, Zakrzewski VG, Dapprich S, Daniels AD, Strain MC, Farkas O, Malick DK, Rabuck AD, Raghavachari K, Foresman JB, Ortiz JV, Cui Q, Baboul AG, Clifford S, Cioslowski J, Stefanov BB, Liu G, Liashenko A, Piskorz P, Komaromi I, Martin RL, Fox DJ, Keith T, Al-Laham MA, Peng CY, Nanayakkara A, Challacombe M, Gill PMW, Johnson B, Chen W, Wong MW, Gonzalez C, Pople JA (2003) Gaussian 03, B01. Gaussian Inc., Pittsburgh, PA

Gackowska A, Przybyłek M, Studziński W, Gaca J (2014) Experimental and theoretical studies on the photodegradation of 2-ethylhexyl 4methoxycinnamate in the presence of reactive oxygen and chlorine species. Cent Eur J Chem 12(5):612-623

Gao L, Yuan T, Zhou C, Cheng P, Bai O, Ao J, Wang W, Zhang H (2013) Effect of four commonly used UV filters on the growth, cell viability and oxidative stress responses of the Tetrahymena thermophila. Chemosphere 93:2507-2513

Gasparro FP (2000) Sunscreens, skin photobiology, and skin cancer: the need for UVA protection and evaluation of efficacy. Environ Health Perspect 108:71-78

Giokas DL, Sakkas VA, Albanis TA (2004) Determination of residues of UV filters in natural waters by solid-phase extraction coupled to liquid chromatogaphy-photodiode array detection and gas chromatography-mass spectromety. J Chrmoatogr A 1026:289-293
Gomez E, Bachelot M, Boillot C, Munaron D, Chiron S, Casellas C, Fenet H (2012) Bioconcentration of two pharmaceuticals (benzodiazepines) and two personal care products (UV filters) in marine mussels (Mytilus galloprovincialis) under controlled laboratory conditions. Environ Sci Pollut Res 19:2561-2569

Gong P, Yuan H, Zhai P, Dong W, Li H (2015) Degradation of organic ultraviolet filter diethylamino hydroxybenzoyl hexyl benzoate in aqueous solution by UV/H2O2. Environ Sci Pollut Res 22(13): 10189-10195

Hauri U, Luetolf B, Schlegel U, Hohl C (2004) Determination of photodegradation of UV filters in sunscreens by HPLC/DAD and HPLC/MS. Mitteilungen aus Lebensmitteluntersuchung und Hygiene 95:147-161

Heneweer M, Muusse M, Van den Berg M, Sanderson JT (2005) Additive estrogenic effects of mixtures of frequently used UV filters on $\mathrm{pS} 2$-gene transcription in MCF-7 cells. Toxicol Appl Pharmacol 208:170-177

Hilton MD, Cain WI (1990) Bioconversion of cinnamic acid to acetophenone by a pseudomonad: microbial production of natural flavor compound. Appl Environ Microbiol 56:623-627

Jammoul A, Dumas S, D'Anna B, George C (2009) Photoinduced oxidation of sea salt halides by aromatic ketones: a source of halogenated radicals. Atmos Chem Phys 9:4229-4237

Kimura K, Katoh T (1995) Photoallergic contact dermatitis from the sunscreen ethylhexyl-p-methoxycinnamate (Parsol MCX). Contact Dermatitis 32(5):304-305

Kolpin DW, Furlong ET, Meyer MT, Thurman EM, Zaugg SD, Barber LB, Buxton HT (2002) Pharmaceuticals, hormones, and other organic wastewater contaminants in U.S. streams, 1999-2000: a national reconnaissance. Environ Sci Technol 36(6):1202-1211

Krishnan R, Binkley JS, Seeger R, Pople JA (1980) Self-consistent molecular orbital methods. XX. A basis set for correlated wave functions. J Chem Phys 72:650-654

Kunz PY, Fent K (2006) Estrogenic activity of UV filter mixtures. Toxicol Appl Pharmacol 217:86-99

Larson RA, Rockwell AL (1979) Chloroform and chlorophenol production by decarboxylation of natural acids during aqueous chlorination. Environ Sci Technol 13(3):325-329

Laturnus F, Fahimi I, Gryndler M, Hartmann A, Heal M, Matucha M, Schöler HF, Schroll R, Svensson T (2005) Natural formation and degradation of chloroacetic acids and volatile organochlorines in forest soil. Challenges to understanding (12 pp). Environ Sci Pollut Res 12(4):233-244

Lebedev AT, Shaydullina GM, Sinikova NA, Harchevnikova NV (2004) GC-MS comparison of the behavior of chlorine and sodium hypochlorite towards organic compounds dissolved in water. Water Res 38:3713-3718

Lee C, Yang W, Parr RG (1988) Development of the Colle-Salvetti correlation-energy formula into a functional of the electron density. Phys Rev B 37:785-789

Lewis FD, Quillen SL, Hale PD, Oxman JD (1988) Lewis acid catalysis of photochemical reactions. 7. Photodimerization and crosscycloaddition of cinnamic esters. J Am Chem Soc 110:1261-1267

Li W, Ma Y, Guo C, Hu W, Liu K, Wang Y, Zhu T (2007) Occurrence and behavior of four of the most used sunscreen UV filters in wastewater reclamation plant. Water Res 41:3506-3512

LiuY S, Ying G-G, Shareef A, Kookana RS (2012) Occurrence and removal of benzotriazoles and ultraviolet filters in a municipal wastewater treatment plant. Environ Pollut 165:225-232

Loraine GA, Pettigrove ME (2006) Seasonal variations in concentrations of pharmaceuticals and personal care products in drinking water and reclaimed wastewater in southern California. Environ Sci Technol 40(3):687-695

MacManus-Spencer LA, Tse ML, Klein JL, Kracunas AE (2011) Aqueous photolysis of the organic ultraviolet filter chemical octyl methoxycinnamate. Environ Sci Technol 45:3931-3937 
McLean AD, Chandler GS (1980) Contracted Gaussian basis sets for molecular calculations. I. Second row atoms, $Z=11-18$. J Chem Phys 72:5639-5648

Michałowicz J (2005) The occurrence of chlorophenols, chlorocatechols and chlorinated methoxyphenols in drinking water of the largest cities in Poland. Pol J Environ Stud 14(3):327-333

Miehlich B, Savin A, Stoll H, Preuss H (1989) Results obtained with the correlation-energy density functionals of Becke and Lee, Yang and Parr. Chem Phys Lett 157:200-206

Miertuš S, Tomasi J (1982) Approximate evaluations of the electrostatic free energy and internal energy changes in solution processes. Chem Phys 65:239-245

Miertuš S, Scrocco E, Tomasi J (1981) Electrostatic interaction of a solute with a continuum. A direct utilization of $\mathrm{AB}$ initio molecular potentials for the prevision of sol vent effects. Chem Phys 55:117-129

Miranda MS, Silva LP, Esteves da Silva JCG (2014) UV filter 2ethylhexyl 4-methoxycinnamate: a structure, energetic and UV-vis spectral analysis based on density functional theory. J Phys Org Chem 27:47-56

Morlière P, Avice O, Melo TS, Dubertret L, Giraud M, Santus R (1982) A study of the photochemical properties of some cinnamate sunscreens by steady state and laser flash photolysis. Photochem Photobiol 36: 395-399

Musa AY, Ba-Abbad MM, Kadhum AAH, Mohamad AB (2012) Photodegradation of chlorophenolic compounds using zinc oxide as photocatalyst: experimental and theoretical studies. Res Chem Intermed 38:995-1005

Nakajima M, Kawakami T, Niino T, Takahashi Y, Onodera S (2009) Aquatic fate of sunscreen agents octyl-4-methoxycinnamate and octyl-4-dimethylaminobenzoate in model swimming pools and the mutagenic assays of their chlorination byproducts. J Health Sci 55: 363-372

Nama S-W, Yoon Y, Choi D-J, Zoh K-D (2015) Degradation characteristics of metoprolol during $\mathrm{UV} /$ chlorination reaction and a factorial design optimization. J Hazard Mater 285:453-463

Negreira N, Canosa P, Rodríguez I, Ramil M, Rubí E, Cela R (2008) Study of some UV filters stability in chlorinated water and identification of halogenated by-products by gas chromatography-mass spectrometry. J Chromatogr A 1178(1-2):206-214

Oppenheimer J, Stephenson R, Burbano A, Liu L (2006) Characterizing the passage of personal care products through wastewater treatment processes. Water Environ Res 18(12):1521-1542

zen AS, Aviyente V (2003) Modeling the oxidative degradation of azo dyes: a density functional theory study. J Phys Chem A 107:48984907

Padmanabhan J, Parthasarathi R, Subramanian V, Chattaraj PK (2005a) Chemical reactivity analysis on $33^{\prime} 44^{\prime} 55^{\prime}$-hexa chlorobiphenyl-a DFT approach. J Mol Struct: THEOCHEM 730:221-226

Padmanabhan J, Parthasarathi R, Subramanian V, Chattaraj PK (2005b) Molecular structure, reactivity, and toxicity of the complete series of chlorinated benzenes. J Phys Chem A 109:11043-11049

Padmanabhan J, Parthasarathi R, Subramanian V, Chattaraj PK (2006a) Chemical reactivity indices for the complete series of chlorinated benzenes: solvent effect. J Phys Chem A 110:2739-2745

Padmanabhan J, Parthasarathi R, Subramanian V, Chattaraj PK (2006b) Group philicity and electrophilicity as possible descriptors for modeling ecotoxicity applied to chlorophenols. Chem Res Toxicol 19:356-364

Palma-Goyes RE, Vazquez-Arenas J, Torres-Palma RA, Ostos C, Ferraro F, González I (2015) The abatement of indigo carmine using active chlorine electrogenerated on ternary Sb2O5-doped Ti/RuO2-ZrO2 anodes in a filter-press FM01-LC reactor. Electrochim Acta 174: 735-744

Pan Z, Stemmler EA, Cho HJ, Fan W, LeBlanc LA, Patterson HH, Amirbahman A (2014) Photocatalytic degradation of $17 \alpha$ - ethinylestradiol (EE2) in the presence of TiO2-doped zeolite. J Hazard Mater 279:17-25

Paredes E, Perez S, Rodil R, Quintana JB, Beiras R (2014) Ecotoxicological evaluation of four UV filters using marine organisms from different trophic levels Isochrysis galbana, Mytilus galloprovincialis, Paracentrotus lividus, and Siriella armata. Chemosphere 104:44-50

Parthasarathi R, Padmanabhan J, Subramanian V, Maiti B, Chattaraj PK (2003) Chemical reactivity profiles of two selected polychlorinated biphenyls. J Phys Chem A 107:10346-10352

Parthasarathi R, Padmanabhan J, Subramanian V, Maiti B, Chattaraj PK (2004) Toxicity analysis of 33'44'5-pentachloro biphenyl through chemical reactivity and selectivity profiles. Curr Sci 86(4):535-542

Pattanaargson S, Limphong P (2001) Stability of octyl methoxycinnamate and identification of its photo-degradation product. Int J Cosmetic Sci 23:153-160

Pattanaargson S, Munhapol T, Hirunsupachot P, Luangthongaram P (2004) Photoisomerization of octyl methoxycinnamate. J Photochem Photobiol A 161:269-274

Pi Y, Wang J (2007) Pathway of the ozonation of 2,4,6trichlorophenol in aqueous solution. Front Environ Sci Engin China 1(2):179-183

Poiger T, Buser H-R, Balmer ME, Bergqvist P-A, Müller MD (2004) Occurrence of UV filter compounds from sunscreens in surface waters: regional mass balance in two Swiss lakes. Chemosphere 55:951-963

Qin F, Zhao YY, Zhao Y, Boyd JM, Zhou W, Li XF (2010) A toxic disinfection by-product, 2,6-dichloro-1,4-benzoquinone, identified in drinking water. Angew Chem Int Ed Engl 49(4):790-792

Ramos S, Homem V, Alves A, Santos L (2015) Advances in analytical methods and occurrence of organic UV-filters in the environmenta review. Sci Total Environ 526:278-311

Ristoiu D, von Gunten U, Mocan A, Chira R, Siegfried B, Haydee Kovacs M, Vancea S (2009) Trihalomethane formation during water disinfection in four water supplies in the Somes river basin in Romania. Environ Sci Pollut Res 16(Suppl 1):55-65

Robinet G, Devillers J, De Bourayne C, Riviere M, Barthelat M (1987) Photodimerization of cinnamate derivatives in microemulsions: investigation by molecular mechanics of the conformations and relative energies of some isomers of the methyl cinnamate dimer. New $\mathbf{J}$ Chem 11:51-59

Rodil R, Moeder M, Altenburger R, Schmitt-Jansen M (2009) Photostability and phototoxicity of selected sunscreen agents and their degradation mixtures in water. Anal Bioanal Chem 395: $1513-1524$

Rodil R, Quintana JB, Concha-Graña E, López-Mahía P (2012) Emerging pollutants in sewage, surface and drinking water in Galicia (NW Spain). Chemosphere 86:1040-1049

Rokhina EV, Suri RPS (2012) Application of density functional theory (DFT) to study the properties and degradation of natural estrogen hormones with chemical oxidizers. Sci Total Environ 417-418:280 290

Sakkas VA, Giokas DL, Lambropoulou DA, Albanis TA (2003) Aqueous photolysis of the sunscreen agent octyl-dimethyl-p-aminobenzoic acid. Formation of disinfection by-products in chlorinated swimming pool water. J Chromatogr A 1016:211-222

Santos AJM, Miranda MS, Esteves da Silva JCG (2012) The degradation products of UV filters in aqueous and chlorinated aqueous solutions. Water Res 46:3167-3176

Santos AJM, Crista DMA, Miranda MS, Almeida IF, Silva JP S e, Costa PC, Amaral MH, Lobão PAL, Sousa Lobo JM, da Silva JCG E (2013) Degradation of UV filters 2-ethylhexyl-4methoxycinnamate and 4-tert-butyl-40-methoxydibenzoylmethane in chlorinated water. Environ Chem 10(2):127-134

Sarkar U, Padmanabhan J, Parthasarathi R, Subramanian V, Chattaraj PK (2006) Toxicity analysis of polychlorinated dibenzofurans through 
global and local electrophilicities. J Mol Struct: THEOCHEM 758: $119-125$

Schauder S, Ippen H (1997) Contact and photocontact sensitivity to sunscreens. Review of a 15-year experience and of the literature. Contact Dermatitis 37(5):221-232

Schlecht C, Klammer H, Wuttke W, Jarry H (2006) A dose response study on the estrogenic activity of benzophenone- 2 on various endpoints in the serum, pituitary and uterus of female rats. Arch Toxicol 80:656-661

Schlumpf M, Cotton B, Conscience M, Haller V, Steinmann B, Lichtensteiger W (2001) In vitro and in vivo estrogenicity of UV screens. Environ Health Perspect 109:239-244

Schrader A, Jakupovic J, Baltes W (1994) Photochemical studies on trans-3-methylbutyl 4-methoxycinnamate. J Soc Cosmet Chem 45: $43-52$

Simões NG, Cardoso VV, Ferreira E, Benoliel MJ, Almeida CM (2007) Experimental and statistical validation of SPME-GC-MS analysis of phenol and chlorophenols in raw and treated water. Chemosphere 68(3):501-510

Solakyildirim K, Bulloch DN, Larive CK (2014) ${ }^{1} \mathrm{H}$ and ${ }^{13} \mathrm{C}$ NMR spectral assignments of halogenated transformation products of pharmaceuticals and related environmental contaminants. Magn Reson Chem 52(6):310-317

Strati IF, Oreopoulou V (2011) Process optimisation for recovery of carotenoids from tomato waste. Food Chem 129(3):747-752

Straub JO (2002) Concentrations of UV filter ethylhexyl methoxycinnamate in the aquatic compartment: a comparison of modeled concentrations for Swiss surface waters with empirical monitoring data. Toxicol Lett 131:29-37

Tarazona I, Chisvert A, León Z, Salvador A (2010) Determination of hydroxylated benzophenone UV filters in sea water samples by dispersive liquid-liquid microextraction followed by gas chromatography-mass spectrometry. J Chromatogr A 1217:4771-4778

Thanikaivelan P, Padmanabhan J, Subramanian V, Ramasami T (2002) Chemical reactivity and selectivity using Fukui functions: basis set and population scheme dependence in the framework of B3LYP theory. Theor Chem Acc 107(6):326-335

Tong AY, Peake B, Braund R (2011) Disposal practices for unused medications around the world. Environ Int 37:292-298

Turnes I, Rodríguez I, García CM, Cela R (1996) Determination of chlorophenols in drinking water with high resolution gas chromatography-tandem mass spectrometry. J Chromatogr A 743(2):283-292

Wols BA, Hofman-Caris CHM, Harmsen DJH, Beerendonk EF (2013) Degradation of 40 selected pharmaceuticals by UV/H2O2. Water Res 47:5876-5888

Yang W, Mortier WJ (1986) The use of global and local molecular parameters for the analysis of the gas-phase basicity of amines. J Am Chem Soc 108:5708-5711

Yasman Y, Bulatov V, Rabin I, Binetti M, Schechter I (2006) Enhanced electro-catalytic degradation of chloroorganic compounds in the presence of ultrasound. Ultrason Sonochem 13:271-277

Zhang S, Chen J, Wang Y, Wei X (2010) Humic acids decrease the photodegradation of the sunscreen UV filter 2-phenylenzimidazole5-sulfonic acid in natural waters. Environ Chem Lett 10:389-394

Zhou L, Ji Y, Zeng C, Zhang Y, Wang Z, Yang X (2013) Aquatic photodegradation of sunscreen agent $\mathrm{p}$-aminobenzoic acid in the presence of dissolved organic matter. Water Res 47:153-162

Zuloaga O, Navarro P, Bizkarguena E, Iparraguirre A, Vallejo A, Olivares M, Prieto A (2012) Overview of extraction, clean-up and detection techniques for the determination of organic pollutants in sewage sluge: a review. Anal Chem Acta 736:7-29 